\title{
How Robust does Pro activeness Influence Social Entrepreneurship Venture Creation with the Moderating Role Social Networks?
}

\author{
Isa Nsereko $^{1}$, John Munene ${ }^{1}$, WaswaBalunywa ${ }^{1}$, Laura Orobia ${ }^{1}$ \\ ${ }^{1}$ Makerere University Business School, Kampala
}

*Corresponding Author: Isa Nsereko, Makerere University Business School, Kampala

\begin{abstract}
Social problem solving has been regarded as the major trigger of entrepreneurial opportunity in new venture development. This is because social problems are all over the world which range from extreme poverty, hunger, poor sanitation, poor education, unemployment, violence, crime and drug abuse. Hence, social entrepreneurs make significant and diverse contributions to their communities by adopting business models to offer creative solutions to complex and persistent social problems. This study investigated how robust pro activeness influences social entrepreneurship venture creation with the moderating role of social networks. The study employed a descriptive survey with quantitative approach. A total number of 243 questionnaires were administered to owners of community based organizations (CBOs) drawn from Kampala district-Uganda. Analysis of data involved the use of statistical package for social sciences (SPSS version 22.0). Hypotheses were tested using hierarchical regression. Results revealed that there is a significant and positive relationship between pro activeness and social entrepreneurial venture creation. Also social networks and social entrepreneurial venture creation were positively related. Finally, there was an interaction between proactiveness and social networks which was also a significant predictor of social entrepreneurial venture creation of CBOs.Like any other research; this study is limited in the following ways. Since only a single research methodological approach was employed, future research could undertake a mixed approach and triangulate to validate the current findings. Further, a longitudinal approach should be employed to study personal initiative-social venture creation trends among CBOs over the years. Finally, factors identified in influencing social venture creation may not be sufficient enough in explaining the phenomenon. Based on the results, there are other factors that may contribute in explaining social venture creation of CBOs that were not part of this study.
\end{abstract}

\section{INTRODUCTION}

Social problem solving has been regarded as the major trigger of entrepreneurial opportunity in new venture development. This is because social problems are all over the world which range from extreme poverty, hunger, poor sanitation, poor education, unemployment, violence, crime and drug abuse (Dees, 1998a; Nicholls, 2006; M. Rivera-Santos, Holt, Littlewood, \& Kolk, 2015; Santos, 2012). Social entrepreneurship is paramount in present day as it renders help to the under-privilege since the world is full of unprecedented calamities that create problems and entrepreneurship activities itself have impacted so much in the areas of job creation and economic growth which are widely recognized across the world (Kritikos, 2014; Valliere\& Peterson, 2009). Individuals have come up with alternative innovative approaches in dealing with community challenges (Bacq \& Lumpkin, 2014; Doherty et al., 2014; Michael Frese \& Gielnik, 2014; Miguel Rivera-Santos, Holt, Littlewood, $\&$ Kolk, 2015). They have provided basic needs like access to clean water, food, clothing, shelter and have employed the disadvantaged/ socially excluded people in their community.

Additionally, they have addressed the biggest societal problems such as HIV, mental ill-health, illiteracy, crime and drug abuse (Helmsing, 2015; Leadbeater, 2007; Zahra \& Wright, 2016).These are social entrepreneurs and their contributions are increasingly being recognised (Burga \& Rezania, 2016; Shaw \& Carter, 2007; Spear, 2006), hence there is need to understand their social entrepreneurial venture creation behaviour. This is illustrated by Dr. Engineer Moses Musaazi's case. Besides, social entrepreneurs are more satisfied and fulfilled when they address social problems irrespective of benefits that may accrue. Achieving this would require unconditional eagerness as some forms of proactive behavior. 
How Robust does Pro activeness Influence Social Entrepreneurship Venture Creation with the Moderating Role Social Networks?

Proactive behavior in organizational behavior and industrial psychology means firms' anticipatory attitude, taking control of situations and initiating actions to make changes. A proactive stance, as opposed to a reactive one, involves acting in advance of a future situation rather than simply responding to a situation that has already happened. For instance a company that takes a proactive stance would recall a faulty line of products rather than wait for customers to complain and deal with the issue down the road.According to George Bernard Shaw, the world has three kinds of people: those who make things happen, those who watch what happens, and those who wonder what happened. Strategy gurus Hamel and Prahalad (1994) make the same point--about firms, not people-with their own metaphor: The key differentiator among these distinctions is the extent to which behavior--of people and firms--is proactive. The most interesting thing about them is their ability to interact and connect with others (social networking).

Social networks are dynamic partnership of people for cross fertilizing social entrepreneurship venture creation. The importance of building social relationships in the field of business has received considerable attention in recent years (Shaw \& Conway, 1999; Hoang \&Antoncic, 2003), and the strategy of bringing individuals and organizations together in formal business networks has been promoted and funded by most government of the world in many sectors. The rationale for this support is the increased access to resources gained from participation in networks which enhances small firm creation and growth. There is an agreement in literature on the role of social networks in resourceful businesses. Entrepreneurship in the 21st century has become reliant on trust and information sharing, access expensive resources such as knowledge and skills at less cost.

Yet, as well researched as the social entrepreneurship venture creation (SEVC) model has been, there is still much work to be done. For example, previous researches have investigated factors such as personal initiative (Frese, 2015; Koop, de Reu and Frese, 2000; Kautonen, van Gelderen \& Fink, 2013; Newbert, 2005), resilience (Cope, 2011; Branzei \& Abdelnour, 2010; Hayward, Forster, Sarasvathy \& Fredrickson, 2010; Tedeschi\& Calhoun, 2004), action mechanisms (Rauch \&Hulsink, 2015; Gielnik et al., 2015; Kolvereid\&Isaksen, 2006; Baum \& Locke, 2004), on social entrepreneurship venture creation (SEVC). However, these studies have used these factors separately to explain social entrepreneurship venture creation (SEVC), thus paying less attention to the combined influence of proactiveness and social networks on CBOs' social entrepreneurship venture creation (SEVC). Going further, in this study the moderating role of social networks on such relationship is considered to be important. Similarly, even though the pro activeness model theoretically recognizes the potential moderating influence of social networks on social entrepreneurship venture creation (SEVC) (Hite \&Hesterly, 2001; Larson \& Starr, 1993; Hoang \& Antoncic, 2003), few studies have actually tested for such moderating effects (e.g., Hoang, H. \& Antoncic, B. (2003). This then suggests that there is still insufficient knowledge (empirical evidence) on the moderating effect of social networks. From the aforementioned gaps in literature, this study revisits the question of whether social networks moderates the relationship between pro activeness and social entrepreneurship venture creation (SEVC).

The rest of the paper is structured as follows: The next section discusses the theoretical background, literature review and hypotheses formulation. This is followed by a description of the approach employed to collect and analyze the data. Thereafter the results are presented. In the last section, conclusions and implications for academics, practitioners and policy makers are presented.

\section{THEORETICAL FRAMEWORK}

For investigating the moderating role of social networks in CBOs' social entrepreneurial venture creation, this study is anchored on social capital theory. The theory is based on the premise that provision of mutual trust, shared beliefs, cultural values, social networks and support are necessary in facilitating cooperation to both the individual and the community (Jackman \& Miller, 1998; Putnam, 1993; Coleman, 1988). Most social entrepreneurs connect themselves with certain networks to gain cooperative action and also obtain relevant information, skills and other resources needed for their businesses. Considering the current study, it can be said that when CBOs connect with the societal environment, they are able to engage in social business activities (Schoger, 2006; Shane \& Cable, 2002; Sideridis \& Chandler, 1997). Adding to that, when they receive support, it will enhance their pro activeness to set up social ventures. This is consistent with Bettcher and Mihaylova (2015) who 
pointed out that social connection is vital for stimulating entrepreneurial activity. This enables them to be exposed to social entrepreneurship to develop better understanding of business start-ups as well as making better decisions in choosing different paths of social entrepreneurial career.

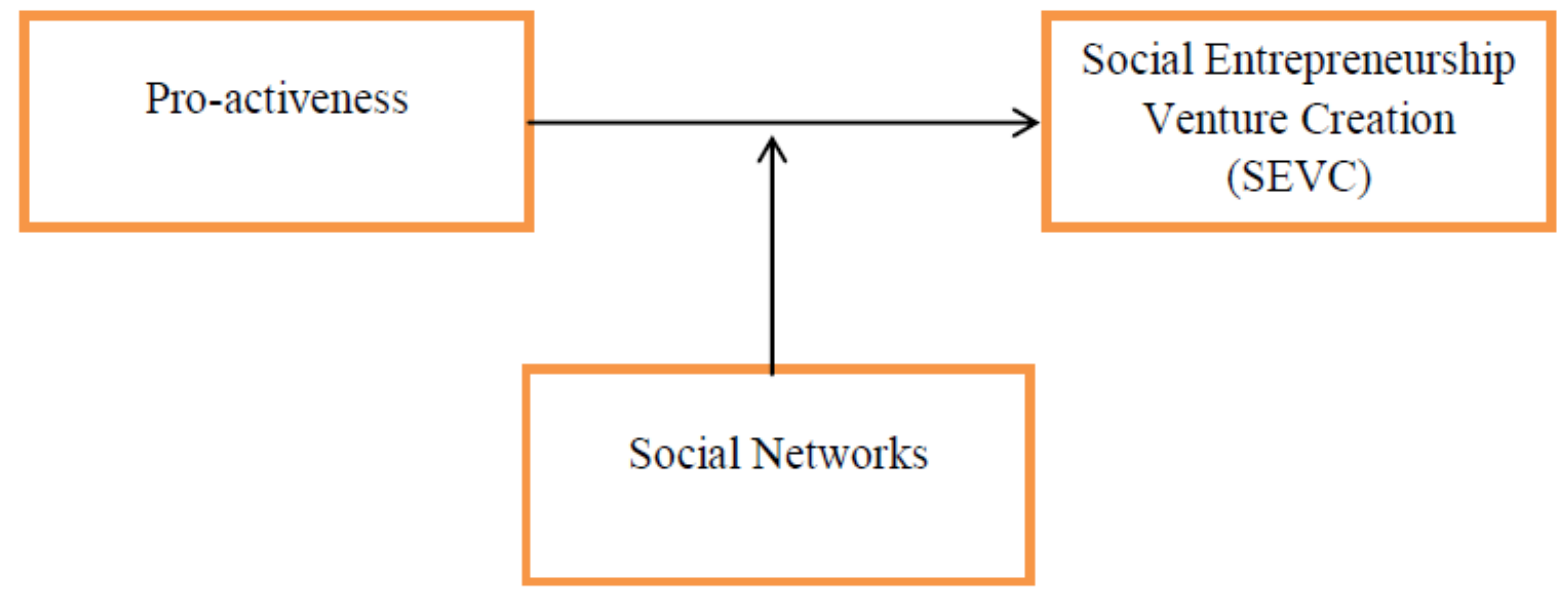

Source: Developed from literature and theories.

The framework shows that pro-activeness (independent variable) has direct effect on social entrepreneurship venture creation (dependent variable) and can be moderated by social networks.

\subsection{Literature Review and Hypotheses Formulation}

This section is intended to provide explanations for the factors that influence social entrepreneurial venture creation in. It has adopted two constructs namely, pro-activeness and social networks which are hypothesized to explain the variance in the social entrepreneurial venture creation. This section therefore covers the review of literature related to the variables under this study. It will provide details relating to both theoretical underpinnings and empirical findings resulting from the previous studies carried out by scholars in different economies and/or institutions.

\subsection{Concept of Pro-Activeness}

This refers to a firm's efforts to seize new opportunities (Lumpkin and Dess, 2001). Pro-activeness is also an opportunity seeking, forward-looking perspective involving the introduction of new products or services ahead of the competition and acting in anticipation of future demand to create change and shape the environment." It involves not only recognizing changes, but also being willing to act on those insights ahead of the competition (Dess and Lumpkin 2005). Kemelgor (2002) defined proactiveness as the extent to which a firm anticipates and acts on future needs. A proactive individual has the ability, willingness and foresight to seize opportunities and in so doing he changes the world and they behave entrepreneurially (Shane and Venkataraman, 2000). Entrepreneurs can be proactive by: shaping the environment; introducing new products and brands in the community. The first mover can capture unusually high profits and get a head start on establishing brand recognition. Proactiveness helps firms proactively seek information and resources to meet anticipated demand (Francis and Collins-Dodd 2000). Lumpkin and Dess, (2001) suggested that pro-activeness leads to increased organizational performance. Individuals with proactive personality identify opportunities and act on them, show initiative, take action, and persevere until meaningful change occurs (Bateman and Crant, 1993). Proactive people strongly believe in their abilities to take actions first and they identify opportunities, act on them, show initiative, and persevere until meaningful change occurs (Crant, 2000).

Proactive people will always have behaviour of starting a new business (Kim, Hon and Crant 2009). Crant (1996) wanted to find out if proactive disposition toward behaviour intuitively appeared to be related to entrepreneurship. The results confirmed that proactive personality was positively associated with entrepreneurial behavioural mechanisms.

\subsection{Concept of Social Entrepreneurial Venture Creation (SEVC)}

This is a set of activities and practices by which individuals generate and use innovative resource combinations to identify and pursue opportunities to solve social problems (Mair, 2002). Behaviour is 
How Robust does Pro activeness Influence Social Entrepreneurship Venture Creation with the Moderating Role Social Networks?

seen as purposive behaviour directed towards a specific event and for the purpose of this study it is a creating a social venture. It has been 'defined as the study of human behaviour involved in identifying and exploiting opportunities through creating and developing new ventures (Bird and Schjoedt, 2009; Kautonen, van Gelderen, and Tornikoski, 2013) as well as exploring and creating opportunities while in the process of emerging organizations (Gartner, Carter, and Reynolds, 2010). It is organized as a proponent to social change and facilitates innovation within established organizations (Kuratko, Ireland, Covin, and Hornsby, 2005). A recent Special Issue on social Entrepreneurial Behaviour emphasizes the importance of refocusing research attention towards concrete and observable human action in venture and organizational creation and emergence (Bird, Schjoedt, and Baum, 2012). The goals of the researchers on social entrepreneurial behaviour will include: to explain, predict and understand the antecedents of social entrepreneurial behaviour that can be learned.

\subsection{Concept of Social Networks}

Social networks provide an entrepreneur with startup capital in most cases. Studies undertaken in Tanzania, India and Germany revealed that entrepreneurs got supported by friends and family and people with who are closely related in the course of starting their business, (Malaki, 2015). The support at this level includes both encouragement of ideas (moral) and financial support. However there is also evidence that in most developing countries social networks drain entrepreneurs' resources due to the redistributive obligation among network members. Obligation to take care of extended families, community members and friends which is obligatory in the African context presents a heavy burden among emerging entrepreneurs. Social networks are useful vehicles enabling entrepreneurs to gain access to valuable resources such as skills, technical advice and sometimes finances which may interfere with pro-activeness. Business motivational is normally affected by the nature of social networks an entrepreneur is part of. This means the opportunities in terms of market and resources to support a social enterprise expand with growth of network among entrepreneurs.

A social network is normally built by like-minded people or people sharing same values. Social networks do promote some forms of social exclusion. Men business networks are women excluding networks the same applies to networks with ethnic root or geographical originality. Alumni networks must exclude some people and includes only those who went through same schools or colleges. At extreme points, social networks can cause problems such as xenophobia. This is because of the social exclusions promoted by the social networks. For instance the immigrant social networks in South Africa caused the xenophobia attacks in 2008 and 2015 respectively. Networks formed by migrants from Nigeria, Kenya, Zimbabwe, Malawi and other countries represents large social networks who support each other economically and socially excluding South African natives by the virtue of their nature. In a study Social Capital in Entrepreneurship in developing Countries, the Case of Uganda" scholars Gerrit Rooks, Adam Szirmai, and Sserwanga (2009) revealed the below findings:

- Women have limited network circles than men counterparts

- The larger the size networks have negative implications to business innovativeness

- Rural entrepreneurs have significantly more access to network resources than their urban counterparts

- Rural networks are more innovative than their urban counterparts

\subsection{Pro-activeness and Social Entrepreneurship Venture Creation}

Entrepreneurs put in a lot of effort to seize new opportunities. (Cui, Sun, Xiao, \& Zhao, 2016; Freiling \& Schelhowe, 2014; Lumpkin, Moss, Gras, Kato, \& Amezcua, 2013).Pro activeness is also an opportunity seeking, forward-looking perspective involving introducing new products or services ahead of the competition and acting in anticipation of future demand to create change and shape the environment." It involves recognizing changes and willingness to act on those insights ahead of the competition. Therefore being proactive is about making things happen, anticipating and preventing problems, and seizing opportunities. It involves self-initiated efforts to bring about change in the work environment and as an individual (self) oneself to achieve certain goals. (Parris \& McInnisBowers, 2014)

Pro-activeness enables a ventures anticipate and act on future needs (Brettel, Chomik, \& Flatten, 2015; Setiawan, Erdogan, \& Ogunlana, 2015; Yeniaras \& Unver, 2016).A proactive individual has the ability, willingness and foresight to seize opportunities. In so doing, he/she changes the world to 
How Robust does Pro activeness Influence Social Entrepreneurship Venture Creation with the Moderating Role Social Networks?

behave in an entrepreneurial (Shane \& Venkataraman, 2000). Social entrepreneurs can be proactive by: shaping the environment; introducing new products and brands in the community. Pro-activeness helps firms to immediately seek for information and resources to meet anticipated demand especially of creating social entrepreneurial ventures (Autio, Pathak, \& Wennberg, 2013b; Gimmon, 2016). Lumpkin et al. (2013); Seelos, Mair, Battilana, \& Tina Dacin (2011); Shepherd (2015a); Suddaby, Bruton, \& Si (2015) suggested that pro-activeness leads to increased initiative to create organizations. Individuals with proactive personality identify opportunities and act on them, show initiative, take action, and persevere until meaningful social change occurs (Bateman \& Crant, 1993). Proactive people strongly believe in their abilities to take actions first and they identify opportunities, act on them and persevere until meaningful change occurs (Swann, 2017). Giving this fact, proactive individuals always have a behavior of starting a new product, service or a new social social business. (Al-Tabbaa, 2017; Autio et al., 2013a; Hwang, Al-Arabiat, Shin, \& Lee, 2016; Joshi, Das, \& Mouri, 2015; Rank, Unger, \& Gemünden, 2015).Drawing from the empirical studies, we hence hypothesized as thus:

H1: Pro-activeness has high robust influence on Social Entrepreneurship Venture Creation.

\subsection{Moderating Role of Social Networks in Social Entrepreneurship Venture Creation}

In the entrepreneurship network literature, we find that three elements of networks emerge as critical to theoretical and empirical research: (1) the nature of the content that is exchanged between actors; (2) governance mechanisms in relationships; and (3) the network structure created by the crosscutting relationships between actors. These three components emerge as key elements in models that seek to explain hairlnethe process of network development during entrepreneurial activity and the impact of networks on entrepreneurial out comes.A key benefit of networks for the entrepreneurial process is the access they provide toinformation and advice. Ties to venture capitalists and professional service organizations, for example, are a means for tapping into key talent and market information (Freeman, 1999). Entrepreneurs continueto rely on networks for business information, advice, and problem solving, with some contacts providing multiple resources (Johannisson et al., 1994).

Going further, scholars have concluded that entrepreneurs rely greatly on their networks formations. They distinguished between the start-up period when the network was used as a safety-net, and more established firm when the network was used "more as a resource bank, managed by both contractual and barter relationships. Similarly, Powell (1990:297) describes how pre-existing networks of relationships enable small firms to gain an established foothold overnight. Networks can be differentiated between those that are established to achieve a specific set of goals (purposive) and those that emerge spontaneously and in which a set of goals may, or may not, emerge during the life of the network. Kilduff \& Tsai (2003) define them as either goal directed networks - which develop consciously and strategically around specific goals that members share - and serendipitous networks in which actors link together individually, by choice, and with no central guidance or overarching objective. Additionally, process-oriented network research focuses on the development and evolution of networks over the venture formation process. To this end, one model has been developed that explores the role of networks in the venture creation process. The potential of networks to assist social enterprise creation and development has been recognized (Haugh, 2005; Hines, 2005; Lyon \& Ramsden, 2006). Drawing from the empirical studies, we hence hypothesized as thus:

H2: Social Networks is positively related with SEVC

H3: Social Networks moderates the relationship between pro-activeness and SEVC

\section{MeTHOdOLOGY}

\subsection{Research Approach}

This research sought to understand further a phenomenon known as "social entrepreneurial venture creation." With the goal of developing a better understanding of the aforementioned phenomena, this research used a self- administered cross sectional survey to identify and draw inferences concerning the relationships between pro activeness, social networks and social entrepreneurial venture creation. Zero-order correlation and hierarchical regression analyses were conducted to investigate the relationships between the variables and the extent to which social networks moderates the relationship between pro activeness and social entrepreneurial venture creation among Ugandan CBOs. 
How Robust does Pro activeness Influence Social Entrepreneurship Venture Creation with the Moderating Role Social Networks?

\subsection{Survey Design}

The self-administered survey was initially designed based on findings from a comprehensive literature review involving proactiveness, social networks and social entrepreneurial venture creation. The initial draft of the survey was then pilottested using entrepreneurship and psychology professors from Makerere University Kampala, a major research university in Uganda, as respondents. Further, the pilot survey was also tested using individuals from 48CBOs as respondents and yielded $95 \%$ response rate. Based on these pilot tests and comments from respondents concerning the clarity of the questions contained within the survey, measurement items were improved as required and any changes were consistent with the guidelines set forth by Dillman (1991); questions were brief and to the point, addressing only a single issue at a time.

In addition, each construct as outlined in the conceptual model proposed by thirsted was measured by at least five questions or items that were created on the basis of established theory. Survey questions were designed to capture perceptions that individuals. Perceptual measures are frequently used inentrepreneurship research since they can parallel objective data inaccuracy and research has supported the use of business owners as the key respondents for questions regarding social venture creation.

\subsection{Common Methods Bias and Non-Response Bias}

Common method bias is a potential problem when all measurements are provided by a single respondent. Common method variance is the portion of the correlation between two variables that results from sharing a common method of measurement (Kearns \& Sabherwal, 2007). Because selfreporting, consistency motif, acquiescence, social desirability, affectivity and transient mood state lead to common method variance; it is of concern in survey research when sampling perceptual data (Podsak off, Mackenzie, Lee, \& Podsak off, 2003). Common method sbias was examined in two ways; firstly we used the strategies to ameliorate the problems of self-report data by designing aquestionnaire to avoid implying that one response is better than the other, paying attention to wording and avoiding socially accepted responses. A common approach of overcoming self-reporting problems is to collect responses from two respondents, however we did not employ this because, firstly our focus was on supplier performance so we could not use them since this would have introduced in bias, secondly it could have introduced errors of linking up data together for predictor and criterion variables, requiring more time, effort and cost. Consistent with Podsak off et al. (2003) we improved item scales by avoiding vague concepts and providing examples where necessary, kept questions simple, specific and concise, avoided double barreled questions, reduced questions relating to more than one possibility into more simple questions and avoided complicated syntax. Secondly common method variance was assessed using Harman's one factor test (Podsak off et al., 2003). The underlying logic for this test is that if common method bias accounts for correlations among variables, then a factor analysis should yield a single factor when all the items are analyzed together. No single factor emerged or one general factor accounted for most of the variance implying that no substantial common method variance was present. On close examination of the output from un rotated factor solution, discriminant validity was also present. Non response bias was examined by two separate tests. First, by comparing the average values for each of the constructs for the first quartile completed questionnaires received versus the last quartile completed questionnaires allowing the late questionnaires to proxy the perceptions of non-respondents. Mean differences for each of the constructs did not reveal any significant difference between the early and late questionnaires (2-tailed t-tests, $\mathrm{p}<0.05$ ). Second, responses were compared by the work force size. Again, acomparison of average work force size from questionnaires for thefirst quartile respondent CBOs to those for the last quartile CBOs didnot reveal any significant difference in the mean of workforce sizes(2-tailed t-test, $\mathrm{p}$ $<0.05$ ). These two comparative tests depicted the absence of non-response bias in this study (Kearns \& Sabherwal, 2007).

\subsection{Refinements to the Measurement Items and Constructs}

The measurement item scales used in the self-administeredsurvey were selected from literature review and used testedinstruments where available. Procedural remedies were observedfrom design to avoid common methods bias for any newmeasurements. Following the guidelines set forth by Podsakoff et al.(2003), the predictor and criterion variables were examined and whatthey had in common was 
How Robust does Pro activeness Influence Social Entrepreneurship Venture Creation with the Moderating Role Social Networks?

eliminated. The reliability of the scaleswas ascertained by performing the Cronbach's alpha coefficient testand all the co-efficients were above 0.7 hence deemed adequate(Nannually, 1967). Content validity checks were also performed onthe constructs to ensure that the scale items were meaningful andcaptured the issues that were being measured and all yielded contentvalidity index above 0.7. A factor analysis was conducted using the Principal ComponentsAnalysis (PCA) approach with varimax rotation to confirm thesuitability of the construct indicators. PCA approach was chosenbecause it provides a linear summarization of the data into simplercomponents and produces exact scores rather than estimates. PCA isalso the simplest of the true eigenvector- based multivariate analysesthat often reveals the internal structure of the data in a way whichbest explains the variance in the data by providing the user with alower-dimensional picture when viewed from its most informativeviewpoint. Varimax rotation generally yields more stable results and iseasier to interpret. A number of meaningful factors, explaining alarger percentage of the common item variance emerged (Podsakoffet al., 2003; Kearns \&Sabherwal, 2007).

Pro-activenesswas measured by examining a person's ability, willingness and foresight to seize new opportunities. It was measured using Bateman \& Crant's (1993) and Michael Frese et al. (1997) selected-items. The items were modified to suit our study since it was used in other countries (Germany and Italy) and on different set of respondents. Responses were indicated on a 5-point Likert scale ranging from 1 (strongly disagree) to 5 (strongly agree), with such items as "I excel at identifying opportunities", "No matter what the odds, if I believe in something I will make it happen", "If I see something I don't like, I fix it', "No matter what the odds, if I believe in something I will make it happen", "I love being a champion for my ideas, even against others' opposition", "I am always looking for better ways to do things".

Social Networksmeasurement was based on scales developed by (Krause \& Borawski-Clark, 1995; Sequeira, Mueller, \& McGee, 2007). The study was anchored on a 5-point Likert scale ranging from 1 (strongly disagree) to 6 (strongly agree).

Question items measuring social entrepreneurial behavior were adapted from Gielniket al. (2015) and modified to suit the Ugandan context. Items such as "Among the various career options, I would be anything but a social entrepreneur", "Being a social entrepreneur would give me great satisfaction", "Being a social entrepreneur implies more advantages than disadvantages to me" were indicated a five-point Likert scale, ranging from one(strongly disagree) to five (strongly agree).

\subsection{Data Collection}

A total sample of 243 owners of community based organizations was drawn from Kampala districtUganda. These CBOs were chosen because of their concentration in Kampala. The participants were selected using simple random sampling technique after which, data were collected through a personal approach and a response rate of $82 \%$ was achieved. The data collection approach was chosen because of the busy nature of our respondents. Additionally, the limited availability and efficiency of postal/communication services in Uganda are unfavourable for questionnaires to be mailed to our respondents. The descriptive statistics revealed that females were more (154) than females (89), with the majority belonging to the 25-31 age bracket $(\mathrm{M}=66 \% ; \mathrm{F}=34 \%)$. With regard to the years of operation, majority $(46.4 \%)$ of the respondents have been in existence between 5years and above and $55.3 \%$ of them have bachelor's qualification. Finally, majority of the respondents $(82.6 \%)$ were married.

\section{FINDINGS}

The ANOVA results in Table 1 were generated to assess proactiveness, social networks and social entrepreneurial venture creation among CBOs in Uganda. The results in the Table 1 shows that there were no significant differences of the CBOs on these study variables ( $p>.05)$.

Table1. ANOVA Results

\begin{tabular}{|l|l|l|l|l|l|}
\hline & Mean & Std Dev. & Std Error & F & Sig \\
\hline Proactiveness & 3.755 & 0.399 & 0.045 & .117 & .950 \\
\hline Social Networks & 3.601 & 0.453 & 0.051 & 1.583 & .194 \\
\hline Social Entrepreneurial Venture Creation & 3.859 & 0.470 & 0.053 & .761 & .516 \\
\hline
\end{tabular}


How Robust does Pro activeness Influence Social Entrepreneurship Venture Creation with the Moderating Role Social Networks?

\subsection{Correlation and Regression Analysis Results}

The results in Table 2 revealed a significant positive relationships between pro activeness and social entrepreneurial venture creation $\left(\mathrm{r}=.209^{* *}, \mathrm{p}<.01\right)$ supporting H1. These results imply that the more owners of CBOs exhibit proactiveness, the more likely it will result into starting a social venture. There was a significant and positive relationship between social networks and social entrepreneurial venture creation $\left(\mathrm{r}=.359^{* *}, \mathrm{p}<.01\right)$ supporting $\mathrm{H} 2$. These results show that if there is an increase in social networking (connections) then social enterprise is likely to be created by social entrepreneurs.

Table2. Correlation Results

\begin{tabular}{|l|l|l|c|}
\hline Variable & \multicolumn{1}{|c|}{$\mathbf{1}$} & \multicolumn{1}{|c|}{$\mathbf{2}$} & $\mathbf{3}$ \\
\hline Pro activeness (1) & $\mathbf{1 . 0 0 0}$ & & \\
\hline Social Networks (2) & $0.430^{* *}$ & $\mathbf{1 . 0 0 0}$ & \\
\hline Social Entrepreneurial Behavior (2) & $0.209^{*}$ & $.359^{* *}$ & $\mathbf{1 . 0 0 0}$ \\
\hline
\end{tabular}

*. Correlation is significant at the 0.05 level (2-tailed).

Consistent with the above, results in Table 3 show the variation explained by the predictor variables (pro activeness and social networks) in the dependent variable (social entrepreneurial venture creation). We chose and applied a hierarchical regression approach to point out the contribution of each predictor in the regression model (Field, 2006). Application of this method also helped us to test the theoretical assumptions and examine the influence of pro activeness and social networks in a sequential way, such that the relative importance of a predictor is judged on the basis of how much it adds to the prediction of a criterion variable.

The regression analysis results provided in Table 3 shows that these predictor variables (pro actiness and social networks) explain $40.5 \%$ of the observed variance in social entrepreneurial venture creation $(\mathrm{R}$ Square $=.405)$.

In Model 1 pro activeness was added and accounted for $17.5 \%$ of the variation in social entrepreneurial venture creation $(\mathrm{R}$ Square $=0.175, \mathrm{R}$ square change $=.175, \mathrm{~F}$ - change $=58.833$ ). This implies that the more owners of CBOs exhibit proactive tendencies, the better they are to start social venture.

Model 2 reveals that pro activeness and social networks are significant predictors accounting for $22.1 \%$ of the variance in social entrepreneurial venture creation. This further shows that pro activeness and social networks for $4.7 \%$ of social entrepreneurial venture creation ( $\mathrm{R}$ Square $=0.22$, $\mathrm{R}$ square change $=.047$, F-change $=16.590$ ).

Table3. Hierarchical Regression Analysis with SEVC as the Dependent Variable

\begin{tabular}{|l|l|l|l|}
\hline & Model 1 & Model 2 & Model 3 \\
\hline Proactiveness (P) & $0.441^{* *}$ & $0.347 * *$ & $0.282^{* *}$ \\
\hline Social Networks (SN) & & $0.329 * *$ & $0.209 * *$ \\
\hline PxSN & & & $0.296^{* *}$ \\
\hline Constant & $2.322^{* *}$ & $1.457 * *$ & $2.787 * *$ \\
\hline Sample (n) & 279 & & \\
\hline R & 418 & .470 & .637 \\
\hline R2 & 0.175 & 0.221 & 0.405 \\
\hline Adj R2 & .172 & 0.216 & 0.399 \\
\hline R square change & .175 & .047 & .184 \\
\hline F Change & 58.833 & 16.590 & 85.393 \\
\hline DF & $(1,278)$ & $(2,277)$ & $(3,276)$ \\
\hline
\end{tabular}

Note: **Significant at 1\%,*Significant at $5 \%$.

Model 3 shows the interaction between pro activeness and social networks which is also a significant predictor of social entrepreneurial venture creation $(\mathrm{R}$ Square $=0.405, \mathrm{R}$ square change $=.184$, Fchange $=85.393$ ). This interaction effect shows the combined power and the complimentary role of pro activeness and social networks.

\section{DISCUSSION AND CONCLUSION}

The study sought to answer the question of how robust pro activeness influences social entrepreneurship venture creation with the moderating role social networks. The findings revealed a 
How Robust does Pro activeness Influence Social Entrepreneurship Venture Creation with the Moderating Role Social Networks?

positive and significant association between proactiveness and social entrepreneurial venture creation which lends support to H1.The findings suggest that when social entrepreneurs are proactive they in turn start a business that solves social problem. This implies that proactive individuals do not wait for events to take their own course, they instead carryout actions like registering, designing a business plan, launch a business before others think of taking any step. In most instances social entrepreneurs in Uganda are seen to be quick in identifying as well as solving socials problems in their communities. This could be seen in Bwaise slums where the community enjoys slums tours, education and good health on account of the proactiveness of social entrepreneurs in their community. This finding is consistent with Frese (2015); Glaub, Frese, Fischer and Hobb (2014) who established that proactive people are the first to take on ideas before others do. They can easily identify what will be done in the future and take on opportunities that have been ignored by others. The study also lends support to Personal Initiative Theory (Frese et al., 1996) which emphasizes proactiveness as a behavioural syndrome that can boost a person to establish social businesses.

Additionally, the findings established that a positive and significant relationship exists between the social network and social entrepreneurial behavior. It also revealed an interaction between proactiveness and social networks which is also a significant predictor of social entrepreneurial venture creationhence providing evidence to support $\mathrm{H} 2$ and $\mathrm{H} 3$. Implying that social entrepreneurs who connect with other counterparts on social needs and problems, take initiatives take active roles in creating businesses that address societal needs and problems. Entrepreneurs continueto rely on networks for business information, advice, and problem solving, with somecontacts providing multiple resources (Johannisson et al., 1994).The finding lends support to the social capital theory which is based on the premise that provision of mutual trust, shared beliefs, cultural values, social networks and support are necessary in facilitating cooperation to both the individual and the community (Jackman\& Miller, 1998; Putnam, 1993; Coleman, 1988). This is consistent with scholars (Haugh, 2005; Hines, 2005) have concluded that entrepreneurs rely greatly on their networks formations. Similarly, Powell (1990) describes how pre-existing networks of relationships enable small firms to gain an established foothold overnight. Networks can be differentiated between those that are established to achieve a specific set of goals (purposive) and those that emerge spontaneously and in which a set of goals may, or may not, emerge during the life of the network. To this end, networks of activities assist social enterprises in the creation and development of social venture(Lyon \&Ramsden, 2006).

\section{STUDY IMPLICATIONS}

\subsection{Theoretical, Methodological and Practical}

This study dwells on how Social Capital theory contributes to theory development in thefield of entrepreneurship by empirically investigating how robust proactiveness influences social entrepreneurship venture creation with the moderating role social networks. The theoretical implication of this study is its contribution to the ongoingsocial entrepreneurship venture creation debate. From the foregoing, it is observed that understanding how social networks moderate social entrepreneurship venture creation of CBOs is key in entrepreneurship. It is upon this backdrop that emphasis ought to be placed on how Ugandan social entrepreneurs will better improve on using their social connectionsin solving the ever rising social problems in their local communities

Methodologically, the study reveals the role of quantitative method approach in predictingsocial entrepreneurialbehaviour. This study builds on prior works in the area of social entrepreneurship venture creation by applying quantitativemethods in studying how robust proactiveness influences social entrepreneurship venture creation with the moderating role social networksof CBOs Uganda. This provides a deeper understanding about the relationships in the concepts of study.

Finally, the practical (managerial) implication of this study focuses on the application of social networks on social entrepreneurship venture creation. Ugandan institutions like Yunus Social of Business (YSB) in Uganda should key into this model by enlightening individuals with networking initiatives in undertaking social entrepreneurship activities. Another managerial implication relatesto providing an enabling environment by the Ugandan government that fosters lifelong social operations for owners of CBOs. 
How Robust does Pro activeness Influence Social Entrepreneurship Venture Creation with the Moderating Role Social Networks?

\subsection{Limitations of the Study and Areas of Further Research}

The study is restricted to Kampala district in Uganda. Further research could be conducted to cover all the owners of Community Based Organisations (CBOs) across the districts in Uganda. Also, this study employed the cross-sectional approach. A longitudinal approach should be employed to study the trend over a period of at least four (4) years. Finally, focusing on pro activeness and social networks in predicting social entrepreneurial venture of CBOs may not be sufficient enough in explaining the phenomenon. Hence, we suggest that scholars should explore other factors such as selfdetermination, behavioural mechanisms, conditional resources and entrepreneurship alertness that may contribute in influencing social entrepreneurial venture creation of CBOs that were not part of this study.

\section{REFERENCES}

[1] Al-Tabbaa, O. (2017). On the Role of Proactiveness: Factors to Determine NGOs Effectiveness in CrossSector Collaboration. SSRN Electronic Journal. https://doi.org/10.2139/ssrn.2943063.

[2] Autio, E., Pathak, S. and Wennberg, K. (2013b). Consequences of cultural practices for entrepreneurial behaviors. Journal of International Business Studies. https://doi.org/10.1057/jibs.2013.15

[3] Bacq, S. and Lumpkin, G. T. (2014). Can Social Entrepreneurship Researchers Learn from Family Business Scholarship? A Theory-Based Future Research Agenda. Journal of Social Entrepreneurship, 5(3), 270-294. https://doi.org/10.1080/19420676.2014.939693

[4] Bateman, T. S. and Crant, J. M. (1993). The proactive component of organizational behavior: A measure and correlates. Journal of Organizational Behavior, 14(2), 103-118. https://doi.org/10.1002/job.403014 0202

[5] Bird, B., Schjoedt, L. and Baum, J. R. (2012). Editor's introduction; Entrepreneurs' behavior: Elucidation and measurement. Entrepreneurship: Theory and Practice, 36(5), 889-913. https://doi.org/10.1111/j.15406520.2012.00535.

[6] Brettel, M., Chomik, C. and Flatten, T. C. (2015). How Organizational Culture Influences Innovativeness, Proactiveness, and Risk-Taking: Fostering Entrepreneurial Orientation in SMEs. Journal of Small Business Management, 53(4), 868-885. https://doi.org/10.1111/jsbm.12108

[7] Burga, R. and Rezania, D. (2016). Stakeholder theory in social entrepreneurship: a descriptive case study. Journal of Global Entrepreneurship Research, 6(1), 4. https://doi.org/10.1186/s40497-016-0049-8

[8] Cui, Y., Sun, C., Xiao, H. and Zhao, C. (2016). How to become an excellent entrepreneur: The moderating effect of risk propensity on alertness to business ideas and entrepreneurial capabilities. Technological Forecasting and Social Change, 112, 171-177. https://doi.org/10.1016/j.techfore.2016.08.002

[9] Dees, J. G. (1998a). The meaning of "social entrepreneurship." Kauffman Foundation and Stanford University, 1-5. https://doi.org/10.2307/2261721

[10] Doherty, B., Haugh, H. and Lyon, F. (2014). Social enterprises as hybrid organizations: A review and research agenda. International Journal of Management Reviews, 16(4), 417-436. https://doi.org/10.1111/ ijmr. 12028

[11] Drasgow, F., Chernyshenko, O. S. and Stark, S. (2010). Improving the measurement of psychological variables: Ideal point models rock! Industrial and Organizational Psychology, 3(4), 515-520. https:// doi.org/ 10.1111/j.1754-9434.2010.01284.

[12] Felder, R. M. and Spurlin, J. (2005). "Applications, reliability and validity of the index of learning styles." International Journal of Engineering Education 21(1): 103-112.

[13] Field, A. (2006). Discovering Statistics using SPSS (2nd ed.). London, UK: Sage Publications.

[14] Freeman, J.(1999). Venture capital as an economy of time. In: Leenders, R.Th.A.J.,Gabbay, S.M. (Eds.), Corporate Social Capital and Liability. Kluwer Academic Publishihing, Boston, pp. 460-482.

[15] Frese, M. and Gielnik, M. M. (2014). The Psychology of Entrepreneurship. Annual Review of Organizational Psychology and Organizational Behavior, 1(1), 413-438. https://doi.org/10.1146/annurevorgpsych-031413-091326

[16] Freiling, J. and Schelhowe, C. L. (2014). The Impact of Entrepreneurial Orientation on the Performance of Internationalization. Journal of Entrepreneurship, Management and Innovation, 10(4), 169-199.

[17] Gartner, W. B., Carter, N. M. and Reynolds, P. D. (2010). Entrepreneurial Behavior: Firm Organizing Processes. Handbook of Entrepreneurship Research, 99-127. https://doi.org/10.1007/978-1-4419-1191-9

[18] Gimmon, E. (2016). The Effect of Entrepreneurial Orientation on SMEs Growth and Export in Israeli Peripheral Regions, 19(2), 2016. 
How Robust does Pro activeness Influence Social Entrepreneurship Venture Creation with the Moderating Role Social Networks?

[19] Hair, J. F. J., R. E. Anderson, et al. (1998). Multivariate data analysis. Upper Saddle River, New Jersey, Prentice Hall.

[20] Helmstater, G. C. (1964). Principles of psychological measurement. New York, Appleton-Century-Crofts.

[21] Hite, J. M. andHesterly, W. S. (2001). The evolution of firm networks: From emergence to early growth of the firm. Strategic Management Journal, 22, 275-286.

[22] Hoang, H. \&Antoncic, B. (2003). Network-based research in entrepreneurship: A critical review. Journal of Business Venturing, 18, 165-187.

[23] Haugh, H. (2007). Community-led social venture creation. Entrepreneurship: Theory and Practice, 31(2), 161-182. https://doi.org/10.1111/j.1540-6520.2007.00168.x

[24] Helmsing, A. H. J. 2015). Conditions for Social Entrepreneurship. International Journal of Social Quality, 5(1). https://doi.org/10.3167/IJSQ.2015.050104

[25] Hwang, Y., Al-Arabiat, M., Shin, D. H. and Lee, Y. (2016). Understanding information proactiveness and the content management system adoption in pre-implementation stage. Computers in Human Behavior, 64, 515-523. https://doi.org/10.1016/j.chb.2016.07.025

[26] Johannisson, B., Alexanderson, O., Nowicki, K., Senneseth, K. (1994). Beyond anarchy and organization: entrepreneurs in contextual networks. Entrepreneurship Reg. Dev. 6, 329-356.

[27] Joshi, M. P., Das, S. R. and Mouri, N. (2015). Antecedents of innovativeness in technology-based services (TBS): Peering into the black box of entrepreneurial orientation. Decision Sciences, 46(2), 367-402. https://doi.org/10.1111/deci.1212

[28] Kaish, S. and Gilad, B. (1991). Characteristics of opportunities search of entrepreneurs versus executives: Sources, interests, general alertness. Journal of Business Venturing, 6(1), 45-61. https://doi.org/10.1016/0883-9026(91)90005-X

[29] Krause, N. and Borawski-Clark, E. (1995). Social class differences in social support among older adults. The Gerontologist, 35(4), 498-508. https://doi.org/10.1093/geront/35.4.498

[30] Kuratko, D. F., Ireland, R. D., Covin, J. G. and Hornsby, J. S. (2005). A model of middle-level managers' entrepreneurial behavior. Entrepreneurship: Theory and Practice. https://doi.org/10.1111/j.15406520.2005.00104.x

[31] Larson, A. and Starr, J. A. (1993). A network model of organizational formation. Entrepreneurship Theory and Practice, Winter, 5-15.

[32] Leadbeater, C. (2007). Social enterprise and social innovation: Strategies for the next ten years. Office, (November), 17. Retrieved from http://community-wealth.org/_pdfs/articles-publications/outside-us/paperleadbeater.pdf

[33] Lumpkin, G. T., Moss, T. W., Gras, D. M., Kato, S. and Amezcua, A. S. (2013). Entrepreneurial processes in social contexts: How are they different, if at all? Small Business Economics, 40(3), 761-783. https://doi.org/10.1007/s11187-011-9399-3

[34] Menold, N. and Tausch, A. (2016). Measurement of Latent Variables With Different Rating Scales: Testing Reliability and Measurement Equivalence by Varying the Verbalization and Number of Categories. Sociological Methods \& Research, 45(4), 678-699. https://doi.org/10.1177/0049124115583913

[35] Rivera-Santos, M., Holt, D., Littlewood, D. and Kolk, A. (2015). Social Entrepreneurship in Sub-Saharan Africa. Academy of Management Perspectives, 29(1), 72-91. https://doi.org/10.5465/amp.2013.0128

[36] Nicholls, A. (2006). Social entrepreneurship: new models of sustainable social change. World (Vol. 2006).Parris, D. L., \& McInnis-Bowers, C. V. (2014). Social Entrepreneurship Questioning the Status Quo: Waste as a Resource. Journal of Economic Issues, 48(2), 359-366. https://doi.org/10.2753/JEI00213624480209

[37] Podsakoff, P. M., Mackenzie, S. B., Lee, J., \&Podsakoff, N. P. (2003). "Common Methods Biases in Behavioral Research: A Critical Review of the Literature and Recommended Remedies." Journalof Applied Psychology, 88(5): 879-903.

[38] Rank, J., Unger, B. N. and Gemünden, H. G. (2015). Preparedness for the future in project portfolio management: The roles of proactiveness, riskiness and willingness to cannibalize. International Journal of Project Management, 33(8), 1730-1743. https://doi.org/10.1016/j.ijproman.2015.08.002

[39] Santos, F. M. (2012). A Positive Theory of Social Entrepreneurship. Journal of Business Ethics, 111(3), 335-351. https://doi.org/10.1007/s10551-012-1413-4

[40] Saris, W. E. and Revilla, M. (2016). Correction for Measurement Errors in Survey Research: Necessary and Possible. Social Indicators Research, 127(3), 1005-1020. https://doi.org/10.1007/s11205-015-1002-X 
How Robust does Pro activeness Influence Social Entrepreneurship Venture Creation with the Moderating Role Social Networks?

[41] Saunders, M., Lewis, P., \& Thornhill, A. (2003). Research Methods for Business Students. Harlow FT Prentice Hall.

[42] Seelos, C., Mair, J., Battilana, J. and Tina Dacin, M. (2011). The Embeddedness of Social Entrepreneurship: Understanding Variation across Local Communities, 3, 333-363. https://doi.org/ 10.1108/S0733-558X(2011)0000033013

[43] Sequeira, J., Mueller, S. L. and McGee, J. E. (2007). The influence of social ties and self-efficacy in forming entrepreneurial intentions and motivating nascent behaviour. Journal of Developmental Entrepreneurship, 12(3), 275-293. https://doi.org/10.1142/S108494670700068

[44] Setiawan, H., Erdogan, B. and Ogunlana, S. O. (2015). Proactiveness of contractors: A study of Indonesia. In Procedia Engineering (Vol. 125, pp. 60-67). https://doi.org/10.1016/j.proeng.2015.11.010

[45] Shane, S. and Venkataraman, S. (2000). THE PROMISE OF ENTREPRENEURSHIP as a Filed of Research. Academy of Management Review, 25(1), 217-226. https://doi.org/10.2307/259271

[46] Shaw, E. and Carter, S. (2007). Social entrepreneurship. Journal of Small Business and Enterprise Development, 14(3), 418-434. https://doi.org/10.1108/14626000710773529

[47] Shepherd, D. A. (2015a). Party On! A call for entrepreneurship research that is more interactive, activity based, cognitively hot, compassionate, and prosocial. Journal of Business Venturing, 30, 489-507. https://doi.org/10.1016/j.jbusvent.2015.02.001

[48] Spear, R. (2006). Social entrepreneurship: a different model? International Journal of Social Economics, 33(5/6), 399-410. https://doi.org/10.1108/03068290610660670

[49] Suddaby, R., Bruton, G. D. and Si, S. X. (2015). Entrepreneurship through a qualitative lens: Insights on the construction and/or discovery of entrepreneurial opportunity. Journal of Business Venturing. https://doi.org/10.1016/j.jbusvent.2014.09.003

[50] Swann, W. L. (2017). Modelling the relationship between entrepreneurial orientation, organizational integration, and programme performance in local sustainability. Public Management Review, 19(4), 542565. https://doi.org/10.1080/14719037.2016.1199729

[51] Tang, J., Kacmar, K. M. M. and Busenitz, L. (2012). Entrepreneurial alertness in the pursuit of new opportunities. Journal of Business Venturing, 27(1), 77-94. https://doi.org/10.1016/j.jbusvent.2010.07.001

[52] Yeniaras, V. and Unver, S. (2016). Revisiting the Mediating Effect of Entrepreneurial Behaviour on Proactiveness - Performance Relationship: The Role of Business Ties and Competitive Intensity. European Management Review, 13(4), 291-306. https://doi.org/10.1111/emre.12084

[53] Zahra, S. A. and Wright, M. (2016). Understanding the Social Role of Entrepreneurship. Journal of Management Studies. https://doi.org/10.1111/joms.12149

Citation: Nsereko, Isa et al. "How Robust does Pro Activeness Influence Social Entrepreneurship Venture Creation with the Moderating Role Social Networks?" International Journal of Managerial Studies and Research (IJMSR), vol 5, no. 11, 2017, pp. 22-33. doi:http://dx.doi.org/10.20431/2349-0349.0511004.

Copyright: (C) 2017 Authors. This is an open-access article distributed under the terms of the Creative Commons Attribution License, which permits unrestricted use, distribution, and reproduction in any medium, provided the original author and source are credited. 